\title{
Restoration and enhancement of Atlantic salmon populations: what we have learned from North Iberian rivers
}

\author{
J.L. Horreo ${ }^{(1)^{\star}}$, J. De La Hoz ${ }^{(2)}$, G. Machado-Schiaffino(1), I.G. Pola ${ }^{(1)}$, \\ E. Garcia-Vazquez ${ }^{(1)}$
}

Received December 3, 2010

Revised August 9, 2011

Accepted November 7, 2011

Key-words: stocking, restoration, connectivity, re-colonization, Salmo salar

\section{Abstract}

Found on the southernmost edge of the species' natural distribution, North Iberian Atlantic salmon populations are extremely vulnerable to environmental change. In the last few decades, associated with global indicators of climate change, these populations have been experiencing a sharp decline. Efforts have been made to address their decline, principally through stocking, supportive breeding and habitat restoration (enabling accessibility to upstream spawning sites). The efficiency of each of these measures has been different. In this study, focused on the river Sella containing one of the largest Spanish populations as a case study, we demonstrate that accessibility and habitat improvement have been the most efficient measures for increasing population size. Supportive breeding accounts for some level of population increase, but generally lower than 10\%. Finally, our review suggests that stocking should be discarded as a restoration method because it encompasses threats to natural variation of Atlantic salmon and also the sympatric brown trout.

\section{RÉSUMÉ}

Restauration et amélioration des populations de saumon Atlantique : ce que nous avons appris de rivières nord-ibériques

\begin{abstract}
Mots-clés : alevinage, restauration, connectivité, recolonisation, Salmo salar
\end{abstract}

\begin{abstract}
Situées en bordure méridionale de la distribution naturelle de l'espèce, les populations nord-ibériques de saumon Atlantique sont extrêmement vulnérables aux changements environnementaux. Dans les dernières décennies, en relation avec les indicateurs globaux du changement climatique, ces populations ont connu une forte baisse. Des efforts ont été faits pour enrayer le déclin, principalement à travers l'alevinage, l'élevage de géniteurs et la restauration de l'habitat (permettant I'accessibilité aux frayères en amont). L'efficacité de chacune de ces mesures a été différente. Dans cette étude, axée sur la rivière Sella contenant l'une des plus grandes populations espagnoles comme étude de cas, nous démontrons que l'accessibilité et l'amélioration de l'habitat ont été les mesures les plus efficaces pour augmenter la taille de la population. L'élevage de soutien de géniteurs représente un certain niveau d'augmentation de la population, mais généralement inférieur à $10 \%$. Enfin, notre étude suggère que l'alevinage doit être abandonné comme méthode de restauration, car elle comporte des menaces à la variabilité naturelle du saumon Atlantique et aussi de la truite fario sympatrique.
\end{abstract}

(1) Department of Functional Biology, University of Oviedo, C/ Julian Claveria s/n, 33006 Oviedo, Spain

(2) Consejería de Medio Ambiente del Principado de Asturias, Ordenación Territorial e Infraestructuras, Plaza de España, 1, Oviedo, 33007, Spain

*Corresponding author: horreojose@gmail.com 


\section{INTRODUCTION}

The Atlantic salmon is an anadromous species sensitive to climate change (e.g. Friedland et al., 2009; Valiente et al., 2010) and to anthropogenic alterations of freshwater habitats (García de Leaniz et al., 1992). The species as a whole has experienced a substantial decline in the last decades, particularly at the southern part of its natural distribution (Parrish et al., 1998; Perez et al., 2005). The species has been a component of the human diet since the Palaeolithic (e.g. Adán et al., 2009). Today there is enormous economic interest in the species, including the importance of farmed salmon to world fin-fish production. Healthy natural populations is the main objective of conservation and restoration in the Northern Hemisphere (i.e. Gephard and McMenemy, 2004).

Preventing declines in population size is crucial for species conservation in order to avoid losses of genetic diversity due to inbreeding and genetic drift. Different restoration measures have been implemented in Atlantic salmon populations. Historically, stocking has been one of the most widely employed. The efficiency of this measure has been questioned, principally based on potential disruption of local adaptation of native populations (Vázquez et al., 1993; Moran et al., 2005). Supportive breeding based on artificial spawning of native adults has also been employed for enhancing many natural populations (Ryman and Laikre, 1991; Blanchet et al., 2008). The main problem reported for this practice is usually related to losses of genetic variation of supportive stocks due to reduced number of breeders (e.g. Verspoor, 1997; Horreo et al., 2008).

Other resources for population enhancement or restoring are related to the recovery of lost spawning areas. Measures aimed at expanding accessible habitat may be more ecologically sound than acting directly on population composition through stocking or supportive breeding. When population declines are due to habitat reduction, for example impassable dams that block the access to upstream spawning areas, facilities enabling connectivity along the river (ladders, elevators) allow upstream accessibility for breeders and subsequent spontaneous population recovery (Budy and Schaller, 2007; Garcia de Leaniz, 2008).

At the south of the European distribution of the species, northern Spanish rivers ( $43^{\circ} \mathrm{N}$ latitude) support small but stable Atlantic salmon populations that exhibit a pattern of genetic population structuring consistent with the metapopulation model with some gene flow occurring between neighbouring rivers (Moran et al., 2005; Ayllon et al., 2006). They have been managed by stocking, supportive breeding and in some cases recovering access to spawning areas previously lost by different human activities, generally construction of hydroelectric facilities. The aim of this work was to examine the effect of different management actions on those populations in order to determine the best strategy for conservation of natural Atlantic salmon populations in northern Spain. We have chosen the River Sella as a representative system in the region in which to undertake this comparison.

\section{MATERIAL AND METHODS}

\section{$>$ CASE STUDY}

We focused on the River Sella (68 km length now accessible for migratory fish) as a case study (Figure 1). This river supports one of the largest Atlantic salmon populations in Spain, yielding a number of sport catches that were, in some years, higher than 1000 (Figure 2). For the last three years the salmon catch in this river has experienced a sharp decline, much greater than the reductions in catch that occurred in the period 1989 and 1997. Besides the main stem of the river, the drainage contains five main tributaries accessible for salmon, the rivers Zardón, Piloña, Gueña, Dobra and Ponga (Figure 1). 


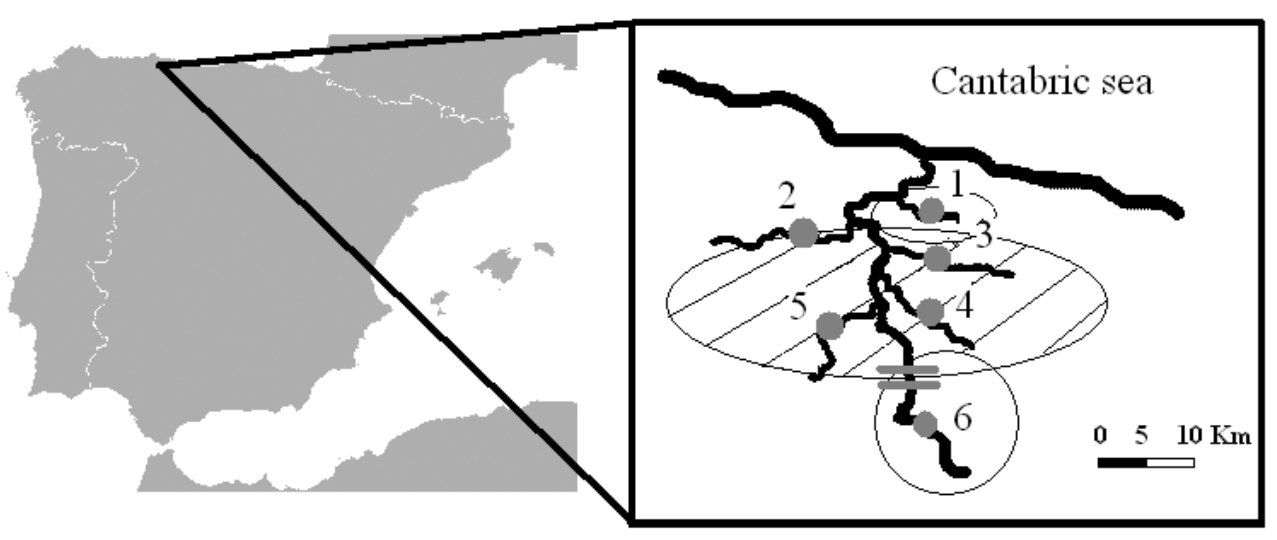

\section{Figure 1}

Location of the sampled River Sella in south Europe. Tributaries of the river: 1-Zardón, 2-Piloña, 3-Gueña, 4-Dobra, 5-Ponga and 6-Alto Sella (grey dots are the sampled points). Circles delimit STRUCTURE genetic units $(\mathrm{K}=3)$. A double grey bar downstream points 6 (Alto Sella) indicates the hydroelectric barrier and the installed fish pass ("La Tejera").

\section{Figure 1}

Localisation de la rivière Sella échantillonnée dans le sud de l'Europe. Les affluents de la rivière : 1-Zardón, 2-Piloña, 3-Guéna, 4-Dobra, 5-6-Ponga et Alto Sella (points gris sont les points échantillonnés). Les éllipses délimitent des unités de structure génétique $(K=3)$. La double barre grise en aval du point 6 (Alto Sella) indique un barrage hydro-électrique et la passe à poissons (« La Tejera »).

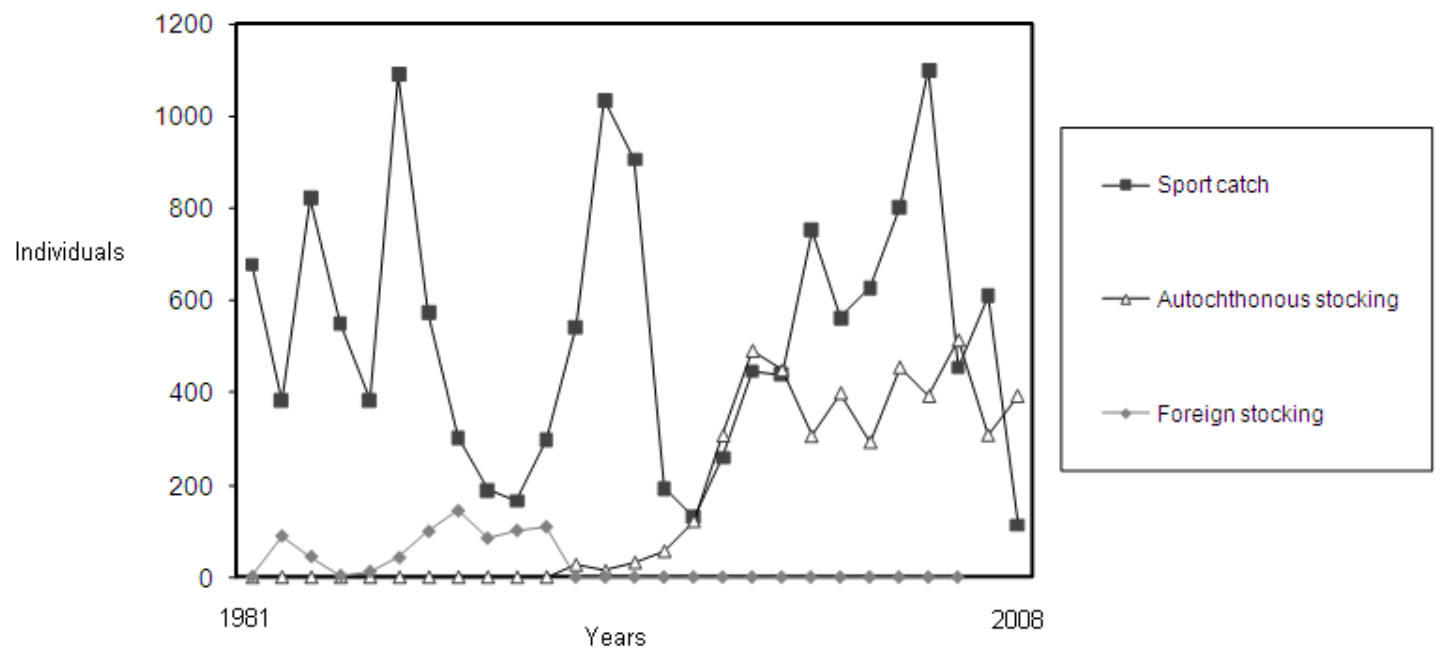

\section{Figure 2}

Sport catch (number of individuals legally caught), foreign stocking and autochthonous supportive breeding (thousands of alevins released into the river) in the River Sella Atlantic salmon population for the last 27 years.

\section{Figure 2}

Captures par pêche (nombre d'individus pêchés légalement), alevinages issus de géniteurs étrangers ou autochtones (en milliers d'alevins déversés dans la rivière) dans la population de saumon Atlantique de la rivière Sella au cours des 27 dernières années. 


\section{> RESTORATION MEASURES}

\section{Foreign stocking}

During the second half of the 20th century, hatchery-origin Atlantic salmon eggs were imported from different countries, and up until 1992, juveniles were released into the rivers of the region. Stocking effort varied depending on years and rivers; in the River Sella the maximum was 145000 juveniles in 1988 (Figure 2). In total 368500,212 600, 63500 and 42500 juveniles from Scotland, Ireland, Iceland and Norway respectively were released into the River Sella from 1981 to 1992.

\section{Autochthonous supportive breeding}

Since 1992, adults returning to the river Sella have been randomly caught for artificial spawning for supportive breeding every year. The ova of each female are artificially fertilized with the sperm of two or three males and some months afterwards (six to eight), juveniles are released into the River Sella. In total, 4550000 juveniles of autochthonous origin were supplemented to the river Sella between 1993 and 2006.

\section{Restoration of habitat connectivity}

The upstream section of the River Sella was blocked by an old hydroelectric facility constructed during the early 20th century (in 1928). It was made accessible to migratory fish by a fish ladder ("Escala Tejera") built in 1995 and made fully functional two years later. The upstream area of the river made accessible to Atlantic salmon by the construction of "Escala Tejera" was approximately $65 \mathrm{~km}^{2}$.

\section{> SAMPLING}

Upstream River Sella (upstream the "Escala Tejera" ladder constructed in 1995; sampling point Alto Sella in Figure 1) was sampled before the construction of the ladder (1994). It was sampled again in 2003 and in 2008. All Salmonids present in approx. $1000 \mathrm{~m}^{2}$ upstream the ladder were caught by electrofishing and tissue (adipose fin clips) obtained for genetic analysis: speciesspecific markers for determining the species in small individuals of ambiguous phenotype, and microsatellite loci in Atlantic salmon.

In 2007 ( $n=190)$ and 2008 ( $n=105)$ Atlantic salmon juveniles were sampled by electrofishing from six more locations within the River Sella drainage (Zardón Piloña, Gueña, Dobra, Ponga and Alto Sella; Figure 1) and analyzed for species-specific markers and microsatellite loci.

We include data of samples obtained before stocking (before 1985) that were reported in previous publications (Ayllon et al., 2006; Castillo et al., 2008).

For estimating the success of supportive breeding practices, adults returning to the river in 2007, 2008 and 2009 at ages 1.1, 2.1-1.2 and 2.2 respectively (the first and second number represent the number of years in freshwater and at sea respectively, as determined from scales following Bagliniere et al., 1986) were analyzed for microsatellites and those issued from the supportive stock were identified by pedigree analysis. Adults were sampled from sport catches. Scales were provided by anglers and employed as DNA source.

\section{> GENETIC ANALYSIS}

\section{Microsatellite loci}

Eight microsatellite loci were analyzed: Ssa197, Ssa202 (O'Reilly et al., 1996), SSsp1605, SSsp2210 and SSspG7 (Paterson et al., 2004), SSOSL417, SSOSL311 and SSOSL85 (Slettan et al., 1995).

Microsatellite PCR amplifications were performed in a total volume of $20 \mu \mathrm{L}$ containing about $50 \mathrm{ng}$ of extracted Atlantic salmon DNA, $10 \mathrm{nM}$ Tris- $\mathrm{HCl} \mathrm{pH} \mathrm{8.8,} 2.5 \mathrm{mM} \mathrm{MgCl}_{2}, 50 \mathrm{mM} \mathrm{KCl}$, 
$0.1 \%$ Triton $\mathrm{x}-100,0.35 \mu \mathrm{M}$ of fluorescently labeled primers, 0.5 Units of DNA Taq Polymerase (Promega) and $250 \mu \mathrm{M}$ of each dNTP. PCR products size determination was performed using an ABI 3100 automatic DNA Sequencer and the GENEMAPPER V.3.5 (Applied Biosystems) software at the DNA Sequencing Unit of the University of Oviedo.

\section{Detection of interspecific hybridization}

Four nuclear species-specific markers were employed for detecting hybridization and introgression. $F_{1}$ hybrids exhibited variants from the two species (Atlantic salmon and brown trout) at the four loci. Post- $F_{1}$ (introgressed) individuals presented variants from one pure species (Salmo salar or S. trutta) at least at one marker, and at least one variant typical of the other species at least one other marker (generally at only one marker). The four markers employed were: 5S rDNA genes (Pendas et al., 1995), Histone-3 coding genes (Perez et al., 1999), transferrin gene (Lee et al., 1998) and the microsatellite locus BFRO 002 (Sušnik et al., 1997). Details about primers and PCR protocols are in Izquierdo et al. (2006). Differences between species at the four loci were detected by PCR-fragment size determination. Labeled primers were employed in the PCR reaction mixture for determining fragment sizes as the microsatellite loci.

\section{> STATISTICAL ANALYSIS}

MICROCHECKER software (Van Oosterhout et al., 2004) was employed to detect possible errors in the microsatellite data as scoring errors, large allele dropout and null alleles. Linkage disequilibrium tests and conformity of genotypes with Hardy-Weinberg equilibrium exact p-values were estimated employing the GENEPOP program (Raymond and Rousset, 1995) with the Markov chain method (10 000 dememorization steps, 10000 batches, 10000 iterations per batch).

Pedigree analyses were performed with the program CERVUS v2.0 (Marshall, 1998) using 10000 cycles, for identifying adult individuals issued from supportive breeding based on microsatellite genotypes. The level of confidence chosen was $95 \%$.

Theta (directly proportional to $N_{\mathrm{e}}: \Theta=4 N_{\mathrm{e}} \mu ; N_{\mathrm{e}}$, effective size; $\mu$, mutation rate) and $M(M=m / \mu$; $m$, immigration rate; $\mu$, mutation rate) values with their correspondent 0.05 and 0.95 percentiles were calculated with the program MIGRATE 2.4.2 (Beerli, 2004), which estimates $N_{\mathrm{e}}$ based on coalescent theory (Beerli and Felsenstein, 2001), relaxing the assumptions of Wright (1951) as in Whitlock and McCauley (1999). Program settings were: three runs with Brownian motion approximation, 10 short chains (1000 recorded steps with increment of 20) and three long chains (10 000 recorded steps with the same increment) with adaptive heating scheme (four heated chains and an interval of one between swapping trees) to ensure that run results do not reflect local likelihood peaks. For estimating $N_{e}$ from Theta, a microsatellite mutation rate of 0.001 was employed (Fraser et al., 2007).

The ARLEQUIN program (Schneider et al. , 2000) was employed for estimating the $F_{\text {ST }}$ statistical significance values between sample pairs with 100 permutations for significance and 10000 steps in Markov chain. The same program was also employed for estimating temporal stability of the population, comparing 2007 and 2008 samples with a molecular analysis of variance (AMOVA) using 10000 permutations. The program STRUCTURE 2.2 (Pritchard et al., 2000) was employed for examining the population structuring of River Sella Atlantic salmon with the following parameter set: length of Burn-in Period: 10 000; Number of MCMC Reps after Burn-in: 10 000; 10 runs for each $K$ ).

Levels of significance for multiple tests were determined using sequential Bonferroni adjustments (Rice, 1989) whenever pertinent.

\section{RESULTS}

Verification of microsatellite data before analysis showed no evidence of linkage disequilibrium generated by physical linkage of pairs of loci within the data set. Genotype frequencies at 


\section{Table I}

Genetic variability of the present River Sella Atlantic salmon populations at eight microsatellite loci studied: sample size (n); outcome of tests for deviations from expected Hardy-Weinberg proportions (HWE); number of alleles per locus for each population (Na); mean heterozygosity expected $(\mathrm{He})$ and observed (Ho); standard deviation (SD). Significance level after sequential Bonferroni correction (Rice, 1989): ${ }^{* *} \mathrm{p}<0.01,{ }^{*} \mathrm{p}<0.05, \mathrm{NS}=$ no significant.

\section{Tableau I}

Variabilité génétique des populations de saumon Atlantique présentes dans la rivière Sella pour huit loci microsatellites étudiés : taille de l'échantillon $(n)$; résultats de tests pour les écarts par rapport aux proportions attendues de Hardy-Weinberg (HWE), nombre d'allèles par locus pour chaque population $(\mathrm{Na})$, moyenne hétérozygotie attendue $(\mathrm{He})$ et observée $(\mathrm{Ho})$; déviation standard $(\mathrm{SD})$. Le niveau de signification, après correction de Bonferroni séquentielle (Rice, 1989) : ** $p<0,01,{ }^{*} p<0,05, \mathrm{NS}=$ non significatif.

\begin{tabular}{|c|c|c|c|c|c|c|c|c|c|c|c|c|}
\hline \multirow[t]{2}{*}{ Sample } & & \multicolumn{8}{|c|}{ Locus } & \multicolumn{3}{|c|}{ Between all loci } \\
\hline & & $\begin{array}{l}\text { Ssa } \\
197\end{array}$ & $\begin{array}{l}\text { Ssa } \\
202\end{array}$ & $\begin{array}{l}\text { SSsp } \\
1605\end{array}$ & $\left|\begin{array}{l}\text { SSsp } \\
2210\end{array}\right|$ & $\begin{array}{c}\text { SSsp } \\
\text { G7 }\end{array}$ & $\begin{array}{c}\text { SSOSL } \\
417\end{array}$ & $\begin{array}{l}\text { SSOS } \\
\text { L } 85\end{array}$ & $\begin{array}{c}\text { SSOSL } \\
311\end{array}$ & $\begin{array}{c}\text { Mean } \mathrm{Na} \\
\text { (ES) }\end{array}$ & $\mathrm{He}(\mathrm{ES})$ & Ho (ES) \\
\hline Alto Sella & $\mathrm{Na}$ & 16 & 9 & 6 & 8 & 11 & 15 & 9 & 13 & 10.87 (3.52) & $0.77(0.09)$ & $0.81(0.10)$ \\
\hline$n=57$ & HWE & NS & NS & NS & NS & NS & NS & NS & NS & & & \\
\hline Ponga & $\mathrm{Na}$ & 9 & 6 & 3 & 5 & 9 & 9 & 6 & 11 & $7.25(2.66)$ & $0.70(0.11)$ & $0.74(0.12)$ \\
\hline$n=22$ & HWE & NS & NS & NS & NS & NS & NS & NS & NS & & & \\
\hline Gueña & $\mathrm{Na}$ & 8 & 5 & 3 & 5 & 3 & 8 & 6 & 6 & $5.50(1.93)$ & $0.69(0.11)$ & $0.69(0.21)$ \\
\hline$n=9$ & HWE & NS & NS & NS & NS & NS & NS & NS & NS & & & \\
\hline Piloña & $\mathrm{Na}$ & 10 & 6 & 4 & 5 & 7 & 10 & 9 & 7 & $7.25(2.25)$ & $0.75(0.12)$ & $0.83(0.11)$ \\
\hline$n=19$ & HWE & NS & NS & NS & NS & NS & NS & NS & NS & & & \\
\hline Zardón & $\mathrm{Na}$ & 13 & 7 & 6 & 10 & 12 & 16 & 10 & 13 & $10.87(3.31)$ & $0.76(0.06)$ & $0.78(0.07)$ \\
\hline$n=45$ & HWE & NS & NS & NS & NS & NS & NS & NS & NS & & & \\
\hline Dobra & $\mathrm{Na}$ & 23 & 8 & 7 & 10 & 15 & 18 & 13 & 19 & 14.00 (5.67) & $0.80(0.08)$ & $0.80(0.09)$ \\
\hline$n=143$ & HWE & ** & * & NS & * & ** & ** & ** & NS & & & \\
\hline
\end{tabular}

individual microsatellite loci were in conformity with Hardy-Weinberg equilibrium in most cases (42 out of 48) after sequential Bonferroni correction for multiple tests, except in the case of the River Dobra, where deviations were caused by heterozygote excess. Variability at the eight microsatellite loci analyzed was relatively high in all salmon samples from the six areas sampled with a total of 128 alleles detected (Table I).

\section{> PRESENT POPULATION STRUCTURE OF RIVER SELLA ATLANTIC SALMON}

The AMOVA did not reveal temporal variation of juveniles sampled in the river in 2007 and 2008 but was significant for variation among locations $\left(F_{C T}=-0.002, p\right.$-value $=0.220$ for variation between years; $F_{\mathrm{SC}}=0.030, p$-value $<0.001$ among locations), therefore the population structure could be considered stable. The results of the two years were therefore pooled by location for subsequent analysis. $F_{\mathrm{ST}}$ values between sample pairs and their corresponding $p$-values (Table II) showed that Atlantic salmon individuals inhabiting different areas (tributaries) of the River Sella exhibited significant differences, all the pairwise comparisons being statistically significant $(p$-values $<0.05)$. These differences are reflected in a structure at drainage level consistent with three genetic units (Table III). Some mixture occurs along the 


\section{Table II}

$F_{S T}$ values between sample pairs of Atlantic salmon populations sampled in the River Sella and their correspondent $\mathrm{p}$-values above the diagonal. Significance level: ${ }^{* *} p<0.01,{ }^{*} p<$ 0.05 .

\section{Tableau II}

Valeurs FST entre les paires d'échantillons de populations de saumon Atlantique échantillonnés dans la rivière Sella et de les $p$-valeurs correspondantes au-dessus de la diagonale. Niveau de signification : ${ }^{* *} p<0,01,{ }^{*} p<0,05$.

\begin{tabular}{|c|c|c|c|c|c|c|}
\hline$F_{\mathrm{ST}}$ & Alto Sella & Ponga & Gueña & Piloña & Zardón & Dobra \\
\hline Alto Sella & - & ** & * & * & ** & ** \\
\hline Ponga & 0.038 & - & ** & ** & ** & ** \\
\hline Gueña & 0.013 & 0.053 & - & ** & ** & ** \\
\hline Piloña & 0.007 & 0.022 & 0.046 & - & *夫 & $\star \star$ \\
\hline Zardón & 0.027 & 0.043 & 0.039 & 0.037 & - & ** \\
\hline Dobra & 0.009 & 0.029 & 0.028 & 0.012 & 0.020 & - \\
\hline
\end{tabular}

\section{Table III}

Summary of STRUCTURE simulations (Pritchard et al., 2000) in order to calculate the genetic units of Atlantic salmon population inhabiting in the river Sella. K, number of genetic units; $S D$, standard deviation.

\section{Tableau III}

Résumé des simulations STRUCTURE (Pritchard et al., 2000) afin de calculer les unités génétiques de populations de saumon atlantique qui sont dans la rivière Sella. K, nombre d'unités génétiques ; SD, écart-type.

\begin{tabular}{|l|c|c|}
\hline$K$ & $\operatorname{Ln} P(D)(S D)$ & $\operatorname{Var}[\operatorname{LnP}(\mathrm{D})](\mathrm{SD})$ \\
\hline $\mathbf{1}$ & $-9566.88(0.36)$ & $64.5(0.59)$ \\
\hline $\mathbf{2}$ & $-9342.38(8.94)$ & $293.6(21.35)$ \\
\hline $\mathbf{3}$ & $\mathbf{- 9 1 5 9 . 2 6 ( 3 0 . 4 1 )}$ & $\mathbf{4 9 4 . 3 ( 5 5 . 5 7 )}$ \\
\hline $\mathbf{4}$ & $-9031.4(32.09)$ & $571.98(43.48)$ \\
\hline $\mathbf{5}$ & $-8978.66(37.39)$ & $752.96(83.58)$ \\
\hline $\mathbf{6}$ & $-8893.36(45.71)$ & $854.84(64.88)$ \\
\hline
\end{tabular}

drainage, where the most differentiated subpopulations were the upstream location Alto Sella and the downstream tributary Zardon (Figure 1; circles delimit STRUCTURE genetic units).

\section{> EFFECT OF FOREIGN STOCKING}

The effect of foreign stocking can be measured by determining the level of introgression of foreign genomes into the local Atlantic salmon population. This introgression was measured as the proportion of individuals of foreign origin detected in River Sella adults sampled in the years 1990, 1992 and 1996 and previously reported by Moran et al. $(1998,2005)$ and Ayllon et al. (2006) respectively, with relatively high levels of introgression being found in the three years (16.2, 2 and $8.3 \%$, respectively).

Interspecific hybridization and introgression(post-F1 hybridization) between salmon and brown trout in the River Sella before, during and after the peak of foreign stocking (1985-1992), were 


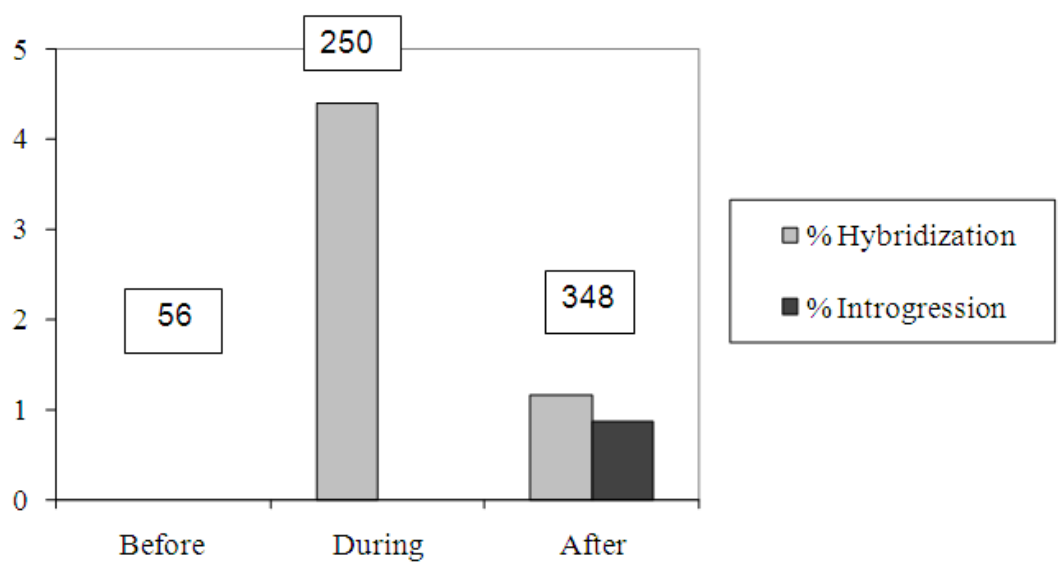

\section{Figure 3}

Interspecific hybridization ( $\mathrm{F} 1$ hybrids) and introgression (post-F1 hybrids), in percent ( $\mathrm{Y}$-axe), occurred in the River Sella before (before 1985), during (1985-1992) and after (2003-2008) the peak of foreign stocking (X-axe), detected by species-specific molecular markers. The total number of individuals analyzed each period of time for species-specific markers is marked above the graph.

\footnotetext{
Figure 3

Hybridation interspécifique (hybrides F1) et l'introgression (post-F1 hybrides), en pour cent (axe Y), observée dans la rivière Sella avant (avant 1985), pendant (1985-1992) et après (2003-2008) le maximum d'alevinage issu de géniteurs étrangers (axe X), détecté par marqueurs moléculaires spécifiques. Le nombre total d'individus analysés à chaque période de temps pour ces marqueurs spécifiques est marqué au-dessus du graphique.
}

detected in this work by species-specific molecular markers (Figure 3). Before the peak of foreign stocking, no hybridization and introgression were detected. During foreign stocking, a high proportion of $F_{1}$ hybrids were detected. Finally, the proportion of $\mathrm{F}_{1}$ decreased but post$F_{1}$ frequency increased ten to 15 years after cessation of stocking. It was detected thanks to the four nuclear species-specific markers employed for detecting hybridization and introgression. Post $-F_{1}$ individuals presented variants from one pure species at least at one marker, and at least one variant typical of the other species at least one other marker.

\section{> EFFECT OF AUTOCHTHONOUS SUPPORTIVE BREEDING}

To quantify the success of autochthonous supportive breeding, pedigree tests were carried out with the breeders of the River Sella hatchery stock (year 2005) as putative parents of the sport catches (adults) in the same river in the years 2007, 2008 and 2009. The percentage of individuals identified as descendents of the hatchery breeders ranged between 4 and $8 \%$ (Table IV) per year, representing $4.2 \%$ of the total catch along the three years.

\section{> EFFECT OF THE FISH LADDER "ESCALA TEJERA"}

The effect of restoring connectivity by constructing the "Escala Tejera" allowed natural recolonisation of Atlantic salmon in the River Sella upstream of the hydroelectric facility. Electrofishing population censuses of brown trout and Atlantic salmon in the area upstream of the old barrier (Figure 4) revealed that within eight years following the restoration of connectivity, Atlantic salmon were present. Only five years later, Atlantic salmon were more abundant than brown trout in that river section.

Theta and $M$ values (indicators of effective population size and migration, respectively), with their corresponding 0.05 and 0.95 percentiles were calculated for the Atlantic salmon 
Table IV

Success of autochthonous supportive breeding. Number (\%) of returns of individuals stocked in 2005 genetically identified within sport catches with their correspondent river and sea age each year.

\section{Tableau IV}

Succès du soutien par l'alevinage à partir de géniteurs autochtones. Nombre (\%), chaque année, des individus issus de l'alevinage de 2005 génétiquement identifiés avec leur âge respectif en rivière et en mer.

\begin{tabular}{|l|c|c|c|c|}
\hline Year & River age & Sea age & Sport catch & Number (\%) of stocked \\
\hline 2007 & 1 & 1 & 89 & $4(4.5 \%)$ \\
\hline 2008 & $1(2)$ & $2(1)$ & 397 & $16(4 \%)$ \\
\hline 2009 & 2 & 2 & 12 & $1(8.3 \%)$ \\
\hline Total & & & 498 & $21(4.2 \%)$ \\
\hline
\end{tabular}

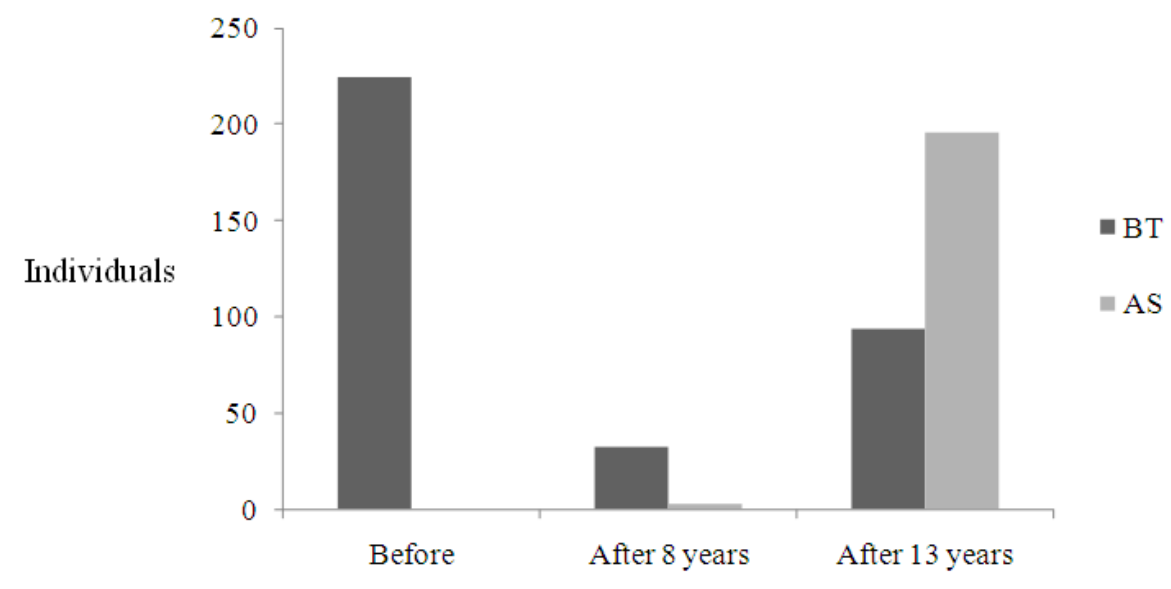

\section{Figure 4}

Spontaneous recovery of upstream River Sella Atlantic salmon population after restoring connectivity. Electrofishing census of $500 \mathrm{~m}^{2}$ upstream section before, during and after the elimination of the ladder "Escala la Tejera". BT, brown trout; AS, Atlantic salmon.

\section{Figure 4}

Rétablissement spontané de la population de saumon Atlantique en amont de la rivière Sella après la restauration de la connectivité. Recensement par pêche électrique dans une section de $500 \mathrm{~m}^{2}$ en amont, avant, pendant et après l'élimination de l'obstacle « Escala La Tejera ». BT, truite fario, AS, saumon Atlantique.

individuals inhabiting upstream Escala Tejera, the new area spontaneously recolonized by the species, and those inhabiting the rest of the river. Theta values were 2.98 [2.77-3.18] for the upstream River Sella (the new area colonized) and 1.33 [1.28-1.38] for the rest of the river. Based on these values of theta, population effective size $\left(N_{\mathrm{e}}\right)$ estimates were 745 [692-795] and 332 [320-345] respectively. The number of migrants from the new area to downstream zones and tributaries was 2.59 [2.41-2.80], while in the opposite direction it was lower, 1.23 [1.12-133].

\section{DISCUSSION}

After 30 years of intense management, including the introduction of large numbers of fish from outside Spain, the River Sella Atlantic salmon population exhibits a relatively high level of 
genetic variability and seems to be in genetic equilibrium. The different areas of the river appear to contain distinct sub-populations (significant $F_{\mathrm{ST}}$ values), with migration between them ( $M$ values) but exhibiting significant spatial population structuring, which is temporally stable and comprising at least two well differentiated units (upstream and downstream) and a mixture in the rest of the drainage. This differs somewhat with the suggestion of the existence of a metapopulation linking neighbouring rivers in this region proposed by Ayllon et al. (2006) and Kuparinen et al. (2010), revealing for the first time the occurrence of fine population structuring at the within river level in northern Spain, as has been described for Atlantic salmon at other latitudes (Ståhl, 1983; Heggberget et al., 1986; Verspoor and Jordan, 1989; Hurrell and Price, 1993; Garant et al., 2000; Spidle et al., 2003; Vähä et al., 2007; Primmer et al., 2006; Dillane et al., 2008).

As already proposed by other authors (Garcia-Vazquez et al., 1991; Vespoor, 1997) stocking with foreign fish should be discarded as a method for restoration and enhancement of this Atlantic salmon population. Amongst other adverse effects, it encompasses introgression of foreign genomes into the wild genome of the autochthonous populations (Moran et al., 1998, 2005; Ayllon et al., 2006), which can endanger local adaptations (Moran et al., 2005). Such introgression not only affects local native Atlantic salmon populations but also other native species, like brown trout (Castillo et al., 2008). The data presented here for the River Sella show both these negative effects occurring (Figure 3).

Supportive breeding seems to be a better method for population enhancement because introgression of foreign genomes is not a risk. However, if few breeders are available and crosses are not carefully planned, genetic variability can be altered and the offspring released into the river may suffer from genetic variation losses (Machado-Schiaffino et al., 2007; Horreo et al., 2008). Depending on the success of such juveniles with reduced variation, the genetic variability of the total population could be also affected and consequently local adaptation endangered (Moran et al., 2005). In the River Sella, where genetic variability reduction had been reported for supportive stocks (Horreo et al., 2008), the success of the supportive breeding for contributing to the increase of the number of adults was relatively low (4.2\%) if compared with that of foreign stocking (ranged between 2-16.2\%; see section 3.2), and therefore it does not seem to be a high risk for the genetic pattern of this particular population. Concerning the efficiency of supportive breeding measures for this river, as stated above in the years considered (2007-2009) the increase of catches was relatively modest.

Restoration of connectivity along the drainage seems to be the best method for restoration and enhancement of Atlantic salmon populations. After eliminating the barrier that impeded accessibility to upstream River Sella areas, Atlantic salmon re-colonized spontaneously those upstream areas and became the most abundant species there in a few years (Figure 4). This could be also due to a reduction in brown trout population. Population size estimates suggest that this recovered spawning habitat yields the largest part of the total effective River Sella Atlantic salmon population size. The new colonized upstream zone exhibits very good spawning habitats, as in most rivers, and is now the largest subpopulation of the River Sella. Higher migration from the upstream zone to other river areas than vice-versa suggests that the Alto Sella subpopulation supports the other subpopulations inhabiting the rest of the river, and emphasizes the value of habitat restoration for population conservation.

This study helps us to assess the capacity of the different types of management implemented in north Spain to enhance and restore Atlantic salmon populations during the last decades. During recent years, supportive breeding has been the most widely practiced management strategy, but it does not seem to have been very effective for real enhancement of these populations. Restoring connectivity along the river and consequently making spawning areas previously closed to Atlantic salmon accessible seems the most successful management action for the restoration and enhancement of endangered populations. Conserving adequate habitat conditions for natural reproduction of Atlantic salmon is therefore necessary and should be a priority for managers. It does not encompass any risk associated to stocking and seems to be more effective than supportive breeding. Stocking should be used only for extreme cases in which total extinction of natural populations has occurred and imports from other regions are necessary. 


\section{ACKNOWLEDGMENTS}

This study has been supported by the European INTERREG project AARC and the Spanish National project CGL2009-08279.

\section{REFERENCES}

Adán G.E., Álvarez-Lao D., Turrero P., Arbizu M. and García-Vázquez E., 2009. Fish as diet resource in North Spain during the Upper Paleolithic. J. Archaeol. Sci., 36, 895-899.

Ayllon F., Martinez J.L. and Garcia-Vazquez E., 2006. Loss of regional population structure in Atlantic salmon, Salmo salar L., following stocking. ICES J. Mar. Sci., 63, 1269-1273.

Bagliniere J.L., Leclerc G. and Richard A., 1986. Comparison of age and growth determination by scale and otolith reading in sea trout Salmo trutta. Bull. Fr. Pêche Pisci., 301, 56-66.

Beerli P., 2004. Effect of unsampled populations on the estimation of population sizes and migration rates between sampled populations. Mol. Ecol., 13, 827-836.

Beerli P. and Felsenstein J., 2001. Maximum likelihood estimation of a migration matrix and effective population sizes in $\mathrm{n}$ subpopulations by using a coalescent approach. Proc. Natl. Acad. Sci. USA, 98, 4563-4568.

Blanchet S., Páez D.J., Bernatchez L. and Dodson J.J., 2008. An integrated comparison of captive-bred and wild Atlantic salmon (Salmo salar): Implications for supportive breeding programs. Biol. Conserv., 141, 1989-1999.

Budy P. and Schaller H., 2007. Evaluating tributary restoration potential for Pacific salmon recovery. Ecol. Appl., 17, 1068-1086.

Castillo A.G.F, Ayllon F., Moran P., Izquierdo J.I., Martinez J.L., Beall E. and Garcia-Vazquez E., 2008. Interspecific hybridization and introgression are associated with stock transfers in salmonids. Aquaculture, 278, 31-36.

Dillane E., McGinnity P., Coughlan J.P., Cross M.C., De Eyto E., Kenchington E., Prodöhl P. and Cross T.F., 2008. Demographics and landscape features determine intrariver population structure in Atlantic salmon (Salmo salar L.): the case of the River Moy in Ireland. Mol. Ecol., 17, 4786-4800.

Fraser D.J., Hansen M.M., Ostergaard S., Tessier N., Legault M. and Bernatchez L., 2007. Comparative estimation of effective population sizes and temporal gene flow in two contrasting population systems. Mol. Ecol., 16, 3866-3889.

Friedland K.D., MacLean J.C., Hansen L.P., Peyronnet A.J., Karlsson L., Reddin D.G., Maoiléidigh N.Ó. and McCarthy J.L., 2009. The recruitment of Atlantic salmon in Europe. ICES J. Mar. Sci., 66, 289-304.

Garant, D., Dodson J.J. and Bernatchez L., 2000. Ecological determinants and temporal stability of the within-river population structure in Atlantic salmon (Salmo salar L.). Mol. Ecol., 9, 615-628.

Garcia de Leaniz C., 2008. Weir removal in salmonid streams: implications, challenges and practicalities. Hydrobiologia, 609, 83-96.

Garcia de Leaniz C., Caballero O., Valero E., Martinez J.J. and Hawkins A.D., 1992. Historical changes in some Spanish rod and line salmon, Salmo salar L., fisheries: why are large multi-sea-winter salmon becoming scarcer? J. Fish Biol., 41, 179.

Garcia-Vazquez E., Morán P. and Pendás A.M., 1991. Chromosome polymorphism patterns indicate failure of a Scottish stock of Salmo salar transplanted into a Spanish river. Can. J. Fish. Aquat. Sci., 48, 170-172.

Gephard S. and McMenemy J., 2004. An overview of the programme to restore Atlantic salmon and other diadromous fishes to the Connecticut River with notes on the current status of these species in the river. Am. Fish. S. M., 9, 287-317.

Heggberget T.G., Lund R.A., Ryman N. and Ståhl G., 1986. Growth and genetic variation of Atlantic salmon (Salmo salar) from different sections of the River Alta, north Norway. Can. J. Fish. Aquat. Sci., 43, 1828-1835.

Horreo J.L., Machado-Schiaffino G., Griffiths A., Bright D., Stevens J. and Garcia-Vazquez E., 2008. Identification of differential broodstock contribution affecting genetic variability in hatchery stocks of Atlantic salmon (Salmo salar). Aquaculture, 280, 89-93.

Hurrell R.H. and Price D.J., 1993. Genetic variation in Atlantic salmon, Salmo salar L., within the Tamar catchment in south-west England. J. Fish Biol., 42, 153-156.

Izquierdo J.I., Castillo A.G.F., Ayllon F., de la Hoz J. and Garcia-Vazquez E., 2006. Stock transfers in Spanish brown trout populations: a long-term assessment. Environ. Biol. Fish., 75, 153-157.

Kuparinen A., Tufto J., Consuegra S., Hindar K., Merilä J. and García de Leaniz C., 2010. Effective size of an Atlantic salmon (Salmo salar L.) metapopulation in Northern Spain. Conserv. Genet., 11, 1559-1565. 
Lee J.Y., Tada T., Hirono I. and Aoki T., 1998. Molecular cloning and evolution of transferrin cDNAs in salmonids. Mol. Mar. Biol. Biotechnol., 7, 287-329

Machado-Schiaffino G., Dopico E. and Garcia-Vazquez E., 2007. Genetic variation losses in Atlantic salmon stocks created for supportive breeding. Aquaculture, 264, 59-65.

Marshall T.C., 1998. Inbreeding and fitness in wild ungulates, Ph.D. thesis, University of Edinburgh.

Moran P., Perez J. and Garcia-Vazquez E., 1998. The malic enzyme in South European Atlantic salmo (Salmo salar); sea age and foreign stocking. Aquat. Sci., 60, 266-359.

Moran P., Perez J., Dumas J., Beall E. and Garcia-Vazquez E., 2005. Stocking-related patterns of genetic variation at enzymatic loci in south European Atlantic salmon populations. J. Fish Biol. , 67, 186-200.

O'Reilly P.T., Hamilton L.C., McConnell S.K. and Wright J.M., 1996. Rapid analysis of genetic variation in Atlantic salmon (Salmo salar L.) by PCR multiplexing of di-nucleotide and tetra-nucleotide microsatellites. Can. J. Fish. Aquat. Sci., 53, 2292-2298.

Parrish D.L., Behnke R.J., Gephard S.R., McCormick S.D. and Reeves G.H., 1998. Why aren't there more Atlantic salmon (Salmo salar)? Can. J. Fish. Aquat. Sci., 55, 281-287.

Paterson S., Piertney B., Knox D., Gilbey J. and Verspoor E., 2004. Characterization and PCR multiplexing of novel highly variable tetranucleotide Atlantic salmon (Salmo salar L.) microsatellites. Mol. Ecol. Notes, 4, 160-162.

Pendas A.M., Moran P., Martinez J.L. and Garcia-Vazquez E., 1995. Applications of 5S rDNA in Atlantic salmon, brown trout, and in Atlantic salmon x brown trout hybrid identification. Mol. Ecol., 4, 275-276.

Perez J., Martinez J.L., Moran P., Beall E. and Garcia-Vazquez E., 1999. Identification of Atlantic salmon $\times$ brown trout hybrids with a nuclear marker useful for evolutionary studies. J. Fish Biol., $54,460-463$.

Perez J., Izquierdo J.I., de la Hoz J. and Garcia-Vazquez E., 2005. Female biased angling harvests of Atlantic salmon in Spain. Fish. Res., 74, 127-133.

Primmer C.R., Veselov A.J., Zubchenko A., Poututkin A., Bakhmet I. and Koskinen M.T., 2006. Isolation by distance within a river system: genetic population structuring of Atlantic salmon, Salmo salar, in tributaries of the Varzuga River in northwest Russia. Mol. Ecol., 15, 653-666.

Pritchard J.K., Stephens M. and Donnelly P.J., 2000. Inference of population structure using multilocus genotype data. Genetics, 155, 945-959.

Raymond M. and Rousset F., 1995. GENEPOP (version 1.2): population genetics software for exact tests and ecumenicism. J. Hered., 86, 248-249.

Rice W.R., 1989. Analyzing tables of statistical tests. Evolution, 43, 223-225.

Ryman N. and Laikre L., 1991. Effects of supportive breeding on the genetically effective population size. Conserv. Biol., 5, 325.

Schneider S., Roessli D. and Excoffier L., 2000. Arlequin ver. 2000: A software for population genetics data analysis. Genetics and Biometry Laboratory, University of Geneva, Switzerland.

Slettan A., Olsaker I. and Lie Ø., 1995. Atlantic salmon, Salmo salar, microsatellites at the SSOSL25, SSOSL85, SSOSL311, SSOSL417 loci. Anim. Genet., 26, 281-282.

Spidle A.P., Kalinowski S.T., Lubinski B.A., Perkins D.L., Beland K.F., Kocik J.F. and King T.L., 2003. Population structure of Atlantic salmon in maine with reference to populations from Atlantic Canada. Trans. Am. Fish. Soc., 132, 196-209.

Ståhl G., 1983. Differences in the amount and distribution of genetic variation between natural populations and hatchery stocks of Atlantic salmon. Aquaculture, 33, 23-32

Sušnik S., Snoj A., Pohar J. and Dovc P., 1997. The microsatellite marker (BFRO 002) characteristic for different geographically remote brown trout, Salmo trutta L., populations. Anim. Genet., 28, 372.

Vähä J-P., Erkinaro J., Niemelä E. and Primmer C.R., 2007. Life-history and habitat features influence the with-river genetic structure of Atlantic salmon. Mol. Ecol., 16, 2638-2654.

Valiente A.G., Beall E. and Garcia-Vazquez E., 2010. Population genetics of south European Atlantic salmon under global change. Glob. Chang. Biol., 16, 36-47.

Van Oosterhout C., Hutchinson W.F., Wills D.P.M. and Shipley P., 2004. MICRO-CHECKER: software for identifying and correcting genotyping errors in microsatellite data. Mol. Ecol. Notes, 4, 535-538.

Vázquez E., Presa P., Sánchez J.A., Blanco G. and Utter F., 1993. Genetic characterization of introduced populations of Atlantic salmon, Salmo salar, in Asturias (Northern Spain). Hereditas, 119, 47-51.

Vespoor E., 1997. Genetic diversity among Atlantic salmon (Salmo salar L.) populations. ICES J. Mar. Sci. , 54, 965-973.

Verspoor E. and Jordan W.C., 1989. Genetic variation at the Me-2 locus in Atlantic salmon within and between rivers: evidence forits selective maintenance. J. Fish Biol., 35, 205-213.

Whitlock, M. C. and McCauley D.E., 1999. Indirect measures of gene flow and migration: F-ST not equal $1 /(4 \mathrm{Nm}+1)$. Heredity, 82, 117-125.

Wright S., 1951. The genetical structure of populations. Annual Eugenics, 15, 323-354. 